\title{
Heat Treatment-Induced Microstructure and Property Evolution of Mg/Al Intermetallic Compound Coatings Prepared by Al Electrodeposition on Mg Alloy from Molten Salt Electrolytes
}

\author{
Tianyu Yao ${ }^{1,2} ®$, Kui Wang ${ }^{1, *}$, Haiyan Yang ${ }^{1, *}$, Haiyan Jiang ${ }^{1}$, Jie Wei ${ }^{1}$, Weiping $\mathrm{Wu}^{3}$, Hezhou Liu ${ }^{2}$, \\ Qudong Wang ${ }^{1}$ and Wenjiang Ding ${ }^{1}$ \\ 1 National Engineering Research Center of Light Alloy Net Forming, Shanghai Jiao Tong University, \\ 800 Dongchuan Road, Minhang District, Shanghai 200240, China; yty123261002@sjtu.edu.cn (T.Y.); \\ jianghy@sjtu.edu.cn (H.J.); weijiesjtu@sjtu.edu.cn (J.W.); wangqudong@sjtu.edu.cn (Q.W.); \\ wjding@sjtu.edu.cn (W.D.) \\ 2 The State Key Lab of Metal Matrix Composites, Shanghai Jiao Tong University, 800 Dongchuan Road, \\ Minhang District, Shanghai 200240, China; hzhliu@sjtu.edu.cn \\ 3 Laboratory of Thin Film Optics, Shanghai Institute of Optics and Fine Mechanics, Chinese Academy of \\ Sciences, 390 Qinghe Road, Jiading District, Shanghai 201800, China; wuwp@siom.ac.cn \\ * Correspondence: fateratory@sjtu.edu.cn (K.W.); yanghaiyan@sjtu.edu.cn (H.Y.)
}

\section{check for} updates

Citation: Yao, T.; Wang, K.; Yang, H.; Jiang, H.; Wei, J.; Wu, W.; Liu, H.; Wang, Q.; Ding, W. Heat TreatmentInduced Microstructure and Property Evolution of $\mathrm{Mg} / \mathrm{Al}$ Intermetallic Compound Coatings Prepared by $\mathrm{Al}$ Electrodeposition on Mg Alloy from Molten Salt Electrolytes. Materials 2021, 14, 1407. https://doi.org/ $10.3390 /$ ma14061407

Academic Editor: Adam Grajcar

Received: 12 February 2021

Accepted: 10 March 2021

Published: 14 March 2021

Publisher's Note: MDPI stays neutral with regard to jurisdictional claims in published maps and institutional affiliations.

Copyright: (c) 2021 by the authors. Licensee MDPI, Basel, Switzerland. This article is an open access article distributed under the terms and conditions of the Creative Commons Attribution (CC BY) license (https:// creativecommons.org/licenses/by/ $4.0 /)$.
Abstract: A method of forming an $\mathrm{Mg} / \mathrm{Al}$ intermetallic compound coating enriched with $\mathrm{Mg}_{17} \mathrm{Al}_{12}$ and $\mathrm{Mg}_{2} \mathrm{Al}_{3}$ was developed by heat treatment of electrodeposition $\mathrm{Al}$ coatings on $\mathrm{Mg}$ alloy at $350{ }^{\circ} \mathrm{C}$. The composition of the $\mathrm{Mg} / \mathrm{Al}$ intermetallic compounds could be tuned by changing the thickness of the $\mathrm{Zn}$ immersion layer. The morphology and composition of the $\mathrm{Mg} / \mathrm{Al}$ intermetallic compound coatings were characterized using scanning electron microscopy (SEM), X-ray diffraction (XRD), and electron backscattered diffraction (EBSD). Nanomechanical properties were investigated via nano-hardness (nHV) and the elastic modulus (EIT), and the corrosion behavior was studied through hydrogen evolution and potentiodynamic (PD) polarization. The compact and uniform $\mathrm{Al}$ coating was electrodeposited on the $\mathrm{Zn}$-immersed AZ91D substrate. After heat treatment, $\mathrm{Mg}_{2} \mathrm{Al}_{3}$ and $\mathrm{Mg}_{17} \mathrm{Al}_{12}$ phases formed, and as the thickness of the $\mathrm{Zn}$ layer increased from 0.2 to $1.8 \mu \mathrm{m}$, the ratio of $\mathrm{Mg}_{2} \mathrm{Al}_{3}$ and $\mathrm{Mg}_{17} \mathrm{Al}_{12}$ varied from 1:1 to 4:1. The nano-hardness increased to $2.4 \pm 0.5 \mathrm{GPa}$ and further improved to $3.5 \pm 0.1 \mathrm{GPa}$. The $\mathrm{Mg} / \mathrm{Al}$ intermetallic compound coating exhibited excellent corrosion resistance and had a prominent effect on the protection of the Mg alloy matrix. The control over the ratio of intermetallic compounds by varying the thickness of the $\mathrm{Zn}$ immersion layer can be an effective approach to achieve the optimal comprehensive performance. As the $\mathrm{Zn}$ immersion time was $4 \mathrm{~min}$, the obtained intermetallic compounds had relatively excellent comprehensive properties.

Keywords: intermetallic compound; $\mathrm{Zn}$ layer; $\mathrm{Al}$ coating; heat treatment; $\mathrm{Mg}_{17} \mathrm{Al}_{12} ; \mathrm{Mg}_{2} \mathrm{Al}_{3}$

\section{Introduction}

$\mathrm{Mg}$ and its alloys have become increasingly promising candidates for structural materials in industrial applications in recent years, due to their low density and high specific strength. However, their poor surface properties, such as corrosion and wear resistance, cannot fulfill industrial demands, thus hindering wider application [1-3]. Inspired by the design of new alloys, surface modification has been regarded as a practical and effective approach to improve surface properties. Various methods of surface modifications, including physical vapor deposition (PVD), chemical vapor deposition (CVD), chemical conversion, anodizing, electrodeposition, electro-less plating, organic coating, laser and ion beams, have been adopted in essentially all cases [4-10].

Among them, surface alloying of $\mathrm{Mg}$ alloys with $\mathrm{Al}$ has been attracting more and more attention since the formation of $\mathrm{Mg} / \mathrm{Al}$ intermetallic compounds can improve corrosion and wear resistance. The typical intermetallic compounds formed by $\mathrm{Mg}$ and $\mathrm{Al}$, that is, 
$\mathrm{Mg}_{17} \mathrm{Al}_{12}$ and $\mathrm{Mg}_{2} \mathrm{Al}_{3}$, show desirable corrosion resistance and wear resistance. Many studies $[11,12]$ have also demonstrated that $\mathrm{Mg} / \mathrm{Al}$ intermetallic compounds, especially $\mathrm{Mg}_{17} \mathrm{Al}_{12}$, exhibited excellent corrosion resistance in chloride solutions. As the $\mathrm{Mg}$ matrix is coated by $\mathrm{Mg}_{17} \mathrm{Al}_{12}$ in chloride solutions, the $\mathrm{Mg}_{17} \mathrm{Al}_{12}$ maintains chemical stability in a wide $\mathrm{pH}$ range, thus improving the corrosion resistance of the alloy.

Numerous studies have been focused on achieving a surface layer of $\mathrm{Mg} / \mathrm{Al}$ intermetallic compounds on $\mathrm{Mg}$ and its alloys, which are composed of $\mathrm{Mg}_{17} \mathrm{Al}_{12}$ and $\mathrm{Mg}_{2} \mathrm{Al}_{3}$. $\mathrm{Bu}$ et al. [13] synthesized $\mathrm{Mg} / \mathrm{Al}$ intermetallic compounds by the cold spray process onto AZ91D magnesium (Mg) substrates. Zhao et al. [14] achieved an $\mathrm{Mg} / \mathrm{Al}$ intermetallic compound coating by $\mathrm{Mg} / \mathrm{Al}$ twin-wire arc spraying. Zhu et al. [11] prepared an Mg/Alalloyed coating onto the surface of magnesium alloy AZ91D via a powder metallurgy process. Although $\mathrm{Mg} / \mathrm{Al}$ intermetallic compounds can be successfully produced using these methods, they could also pose some problems. Firstly, the preparation process requires a high working temperature, and thus makes the thickness and the uniformity of the intermetallic compounds layer uncontrollable. Secondly, the uncontrollable diversity of the thickness and the uniformity of the intermetallic compounds layer leads to poor corrosion resistance, so the layer may not be capable of protecting the matrix sufficiently. What is more, the composition of the $\mathrm{Mg} / \mathrm{Al}$ intermetallic compounds layer is determined and unmodifiable, which makes it impossible to improve the performance by tuning different components.

It is well-documented that electrodeposition is one of the most effective methods to fabricate coatings and films because of its convenience, simplicity, and cost-effectiveness [15]. Furthermore, the compactness and thickness of the coatings can be controlled by altering the processing parameters of electrodeposition. Electrodeposition is the optimal solution to get $\mathrm{Al}$ coatings onto $\mathrm{Mg}$ alloy with regular structure, smooth surface, and controllable thickness [16]. After electrodeposition, heat treatment is employed to form $\mathrm{Mg} / \mathrm{Al}$ intermetallic compounds [17]. The thickness and quality of the Al coatings can be tailored through optimization of the processing parameters of electrodeposition. On the other hand, it has been demonstrated $[18,19]$ that the addition of $\mathrm{Zn}$ favors the formation of $\mathrm{Mg} / \mathrm{Al}$ intermetallic compounds through diffusion at a low temperature. Therefore, if the process of $\mathrm{Zn}$ immersion is performed before the electrodeposition of $\mathrm{Al}$ onto $\mathrm{Mg}$ alloy, it is expected that the introduction of $\mathrm{Zn}$ could facilitate the formation of $\mathrm{Mg}_{17} \mathrm{Al}_{12}$ and $\mathrm{Mg}_{2} \mathrm{Al}_{3}$ phases during the heat treatment [20], which helps to produce the composition-controllable $\mathrm{Mg} / \mathrm{Al}$ intermetallic compound coatings.

In the present study, a novel two-step method of forming an $\mathrm{Mg} / \mathrm{Al}$ intermetallic coating that is enriched with $\mathrm{Mg}_{17} \mathrm{Al}_{12}$ and $\mathrm{Mg}_{2} \mathrm{Al}_{3}$ was developed. The composition of $\mathrm{Mg}_{17} \mathrm{Al}_{12}$ and $\mathrm{Mg}_{2} \mathrm{Al}_{3}$ could be tuned by changing the thickness of the $\mathrm{Zn}$ immersion layer so that $\mathrm{Mg} / \mathrm{Al}$ intermetallic coatings with different performance preferences could be obtained. Step one was to prepare the $\mathrm{Mg}-\mathrm{Zn}-\mathrm{Al}$ composite coatings through the electrodeposition of $\mathrm{Al}$ from $\mathrm{AlCl}_{3}-\mathrm{NaCl}-\mathrm{KCl}(80-10-10 \mathrm{wt} . \%)$ molten salt electrolytes onto AZ91D $\mathrm{Mg}$ alloy. Step two was to obtain the layer of thick $\mathrm{Mg} / \mathrm{Al}$ intermetallic coatings, which were enriched with $\mathrm{Mg}_{17} \mathrm{Al}_{12}$ and $\mathrm{Mg}_{2} \mathrm{Al}_{3}$, through a vacuum heat treatment at $350{ }^{\circ} \mathrm{C}$. The effect of heat treatment on the morphology and microstructures of $\mathrm{Al}$ was studied systematically. The morphology and composition of the $\mathrm{Mg} / \mathrm{Al}$ intermetallic coatings were characterized using scanning electron microscopy (SEM), X-ray diffraction (XRD), and electron backscattered diffraction (EBSD). Additionally, the corrosion performance was also evaluated and the corrosion behavior was studied through potentiodynamic (PD) polarization.

\section{Materials and Methods}

\subsection{Zn Immersion}

AZ91D Mg alloy (as-cast, Mg-9 wt.\% Al-1 wt.\% Zn) was used in this research. Specimens were cut into small bars with a size of $5 \mathrm{~mm} \times 5 \mathrm{~mm} \times 100 \mathrm{~mm}$. Before Zn immersion, each sample was ground with $\mathrm{SiC}$ papers to 1500 grit, and then degreased ultrasonically in 
an ethanol solution for $3 \mathrm{~min}$. A layer of $\mathrm{Zn}$ was obtained by the following steps: pickling $\rightarrow$ conditioning $\rightarrow$ activation $\rightarrow \mathrm{Zn}$ immersion. The solution compositions and operation conditions are shown in Table 1. Different $\mathrm{Zn}$ immersion times, $2 \mathrm{~min}, 4 \mathrm{~min}, 6 \mathrm{~min}$, and $8 \mathrm{~min}$, were adopted in this experiment.

Table 1. The solution compositions and operation conditions of $\mathrm{Zn}$ immersion.

\begin{tabular}{ccccc}
\hline Process & Bath Compositions & Content & Conditions & Time \\
\hline Pickling & $\mathrm{C}_{6} \mathrm{H}_{8} \mathrm{O}_{7}$ & $40 \mathrm{~g} / \mathrm{L}$ & Room Temperature & $2 \mathrm{~min}$ \\
Conditioning & $\mathrm{NaOH}$ & $200 \mathrm{~g} / \mathrm{L}$ & Room Temperature & $10 \mathrm{~min}$ \\
Activation & $\mathrm{C}_{6} \mathrm{H}_{8} \mathrm{O}_{7}$ & $20 \mathrm{~g} / \mathrm{L}$ & Room Temperature & $40 \mathrm{~s}$ \\
$\mathrm{Zn}$ immersion & $\mathrm{ZnSO}_{4} \cdot 7 \mathrm{H}_{2} \mathrm{O}$ & $30 \mathrm{~g} / \mathrm{L}$ & $80{ }^{\circ} \mathrm{C}$ & $2 \sim 8 \mathrm{~min}$ \\
& $\mathrm{Na}_{4} \mathrm{P}_{2} \mathrm{O}_{7} \cdot 10 \mathrm{H}_{2} \mathrm{O}$ & $120 \mathrm{~g} / \mathrm{L}$ & & \\
& $\mathrm{NaF}$ & $5.5 \mathrm{~g} / \mathrm{L}$ & & \\
& $\mathrm{Na}_{2} \mathrm{CO}_{3}$ & $5.5 \mathrm{~g} / \mathrm{L}$ & & \\
\hline
\end{tabular}

\subsection{Electrodeposition and Heat Treatment}

Sodium chloride ( $\mathrm{NaCl}, \mathrm{AR}, 99.9 \%$ purity) and potassium chloride $(\mathrm{KCl}, \mathrm{AR}, 99.9 \%$ purity) were kept in a vacuum drying chamber at $300^{\circ} \mathrm{C}$ for $72 \mathrm{~h}$ before the experiment to remove moisture. Anhydrous $\mathrm{Al}$ chloride $\left(\mathrm{AlCl}_{3}, \mathrm{AR}, 99.8 \%\right.$ purity) was used as received. $\mathrm{AlCl}_{3}, \mathrm{NaCl}$, and $\mathrm{KCl}(80-10-10 \mathrm{wt} . \%)$ were mixed and melted at $150^{\circ} \mathrm{C}$ in a radius flask on a temperature-controlled heater inside a glove box (Mikrouna Upure 1220/750/900, Shanghai, China), which was purged with high-purity Ar gas. The mixture was continuously stirred with a magnetic stirrer for more than $4 \mathrm{~h}$ to yield a homogeneous light yellow liquid.

All of the electrodeposition experiments were carried out using an electrochemical workstation (CHI655D, Shanghai Chenhua Device Company, Shanghai, China) in the glove box. An Al plate $\left(99.99 \%, 350 \mathrm{~mm}^{2}\right)$ and a pure $\mathrm{Al}$ bar $(99.99 \%$, diameter $\Phi=0.5 \mathrm{~mm})$ were used as the counter electrode and the reference electrode. The Mg alloy bar after the $\mathrm{Zn}$ immersion pretreatment was connected as the cathode. A $10 \mathrm{~mm}$-wide interval was maintained between the cathode and the anode. All of the electrode materials were cleaned and dried before they were transferred into the glove box. Cathodic deposition of $\mathrm{Al}$ was performed under a constant current mode at $150{ }^{\circ} \mathrm{C}$ with a current density of $50 \mathrm{~mA} \cdot \mathrm{cm}^{-2}$, and the process of electrodeposition lasted for $10 \mathrm{~min}$.

After the electrodeposition, the samples were cleaned completely using anhydrous acetone in an ultrasonic bath for $2 \mathrm{~min}$, rinsed with deionized water, and then dried in the vacuum drying chamber. The samples of the electrodeposition $\mathrm{Al}$ coatings on the $\mathrm{Mg}$ alloys were heat-treated in a vacuum oven (SX2-4-10Z, Shanghai Boxun Device Company, Shanghai, China) with a vacuum pressure of $<10^{-3} \mathrm{~Pa}$ at $350{ }^{\circ} \mathrm{C}$ for $4 \mathrm{~h}$ and cooled down to room temperature in the furnace.

\subsection{Characterization}

A field emission scanning electron microscope (FE-SEM, SIRION200, FEI, Hillsboro, OR, USA) was used to observe the surface and cross-sectional morphologies of the Al coatings. The samples were examined by X-ray diffraction (XRD, D/MAX2000 V, Rigaku, Japan) to identify the constituents and the crystal structure by the $2 \theta / \theta$ scanning mode. The data was collected in a $2 \theta=30^{\circ}-80^{\circ}$ range with a scanning speed of $5^{\circ} \cdot \mathrm{min}^{-1}$ with a 0.01 degree (2 $\theta)$ step size. The obtained data were compared with the International Centre for Diffraction Data (ICDD) Card No. 004-0787 to identify the element.

Nanoindentation tests were performed on the cross-section of each sample with a nanohardness instrument (NST, CSM0200, CSM, Lausanne, Switzerland). (The nanoindentation tests were conducted on the surface of the $\mathrm{Zn}$ layers, since they were too thin.) The indentation load was set at $2000 \mu \mathrm{N}$ and the loading/unloading rate was kept constant at $4000 \mu \mathrm{N}$ per minute. The stabilization time between the loading and unloading stages was fixed at $5 \mathrm{~s}$. There were 5 indentations taken, and the distance between each indentation 
was $10 \mu \mathrm{m}$ to eliminate the overlap of the indentations. The nano-hardness was calculated as the average of the 5 data points. The elastic modulus (EIT) and nano-hardness (nHV) were calculated from the load-displacement curves as per [21]. The values of the EIT were determined from the slope (S) of the unloading curve by the equation below. Specifically, it was a measurement of the elastic properties of the different surfaces [22].

$$
E_{r}=\frac{S}{2} \sqrt{\frac{\pi}{A}}
$$

where $A$ is the projected area after the indentation.

The hydrogen evolution experiments were performed to measure the cumulative corrosion evolved during the extended period of immersion in $3.5 \mathrm{wt}$. $\% \mathrm{NaCl}$ solution at room temperature for $136 \mathrm{~h}$. The $\mathrm{NaCl}$ solutions were prepared with deionized water and were not deaerated. An upside-down burette tube filled with the same solution was placed over the sample during the tests to collect evolved hydrogen gas. Before the immersion, the samples were cold-mounted in epoxy resin with a copper wire attached, and an exposed surface area of $0.25 \mathrm{~cm}^{2}(5 \mathrm{~mm} \times 5 \mathrm{~mm})$ was adopted to assure that all the corrosion occurred here. For each kind of sample, the hydrogen evolution experiments were carried out three times. In order to evaluate the corrosion resistance, the electrochemical behavior was also studied by potentiodynamic polarization (PD). The PD tests were performed in the $3.5 \mathrm{wt} \% \mathrm{NaCl}$ solution at room temperature. The counter electrode and the reference electrode were a graphite electrode and a saturated calomel electrode (SCE), respectively. All the samples remained at the open circuit for $30 \mathrm{~min}$ to reach a steady value before the PD tests. Scans were obtained from $100 \mathrm{mV}$ below the open circuit potential (OCP) and scanned upwards at a rate of $0.5 \mathrm{mV} / \mathrm{s}$. The corrosion current density $\left(\mathrm{i}_{\text {corr }}\right)$ and corrosion potential $\left(\mathrm{E}_{\mathrm{corr}}\right)$ were calculated by the Tafel extrapolation.

\section{Results and Discussion}

\subsection{As-Deposited Microstructures}

Figure 1a-d shows the planar view SEM images of the Zn layers on the AZ91D alloys that underwent different immersion times. Figure $1 \mathrm{e}-\mathrm{h}$ depicts the cross-sectional morphologies of the $\mathrm{Zn}$ layer on the AZ91D Mg alloys. It can be seen that the surface and cross-sectional morphologies of the Zn layer varied significantly. As the Zn immersion time reached $2 \mathrm{~min}$, shown in Figure 1a,e, the distribution of the $\mathrm{Zn}$ particles on the $\mathrm{Mg}$ alloys was not uniform, which means an inhomogeneous and discontinuous Zn layer was obtained. The cross-sectional morphology showed that the $\mathrm{Zn}$ layer was quite thin, with a thickness of $0.2 \mu \mathrm{m}$. With the increase of the $\mathrm{Zn}$ immersion time, the densification and thickness of the Zn layer increased gradually and obviously. After an 8-min Zn immersion, as shown in Figure $1 \mathrm{~d}, \mathrm{~h}$, the surface of the $\mathrm{Mg}$ alloy was completely covered by $\mathrm{Zn}$, and a uniform and dense $\mathrm{Zn}$ layer with good flatness was obtained. The matrix was dark grey, while the $\mathrm{Zn}$ layer became bright white, and the thickness was increased to $1.8 \mu \mathrm{m}$ since there was abundant $\mathrm{Zn}$ deposited on the $\mathrm{Mg}$ alloy. Controlling the time of the $\mathrm{Zn}$ immersion is a simple and effective method to adjust the compactness and thickness of the Zn layer.

Figure $2 \mathrm{a}-\mathrm{d}$ shows the planar view SEM images of the Al coating on the $\mathrm{Zn}$-immersed AZ91D alloys with different immersion times. The surface of the Al coating was compact and uniform, which had no significant change with increases in the Zn immersion times. Such a finely deposited Al coating was mainly attributed to the $\mathrm{Zn}$ immersed on the substrate, compared with the Al coating on bare AZ91D, according to our previous work [23]. Figure $2 \mathrm{e}-\mathrm{h}$ demonstrates the cross-sectional morphologies of the Zn-immersed AZ91D $\mathrm{Mg}$ alloys with an $\mathrm{Al}$ coating. A general morphology of the sandwich structure can be observed: a grey $\mathrm{Al}$ layer coated on $\mathrm{Mg}$ substrate, sandwiched with a $\mathrm{Zn}$ layer. 


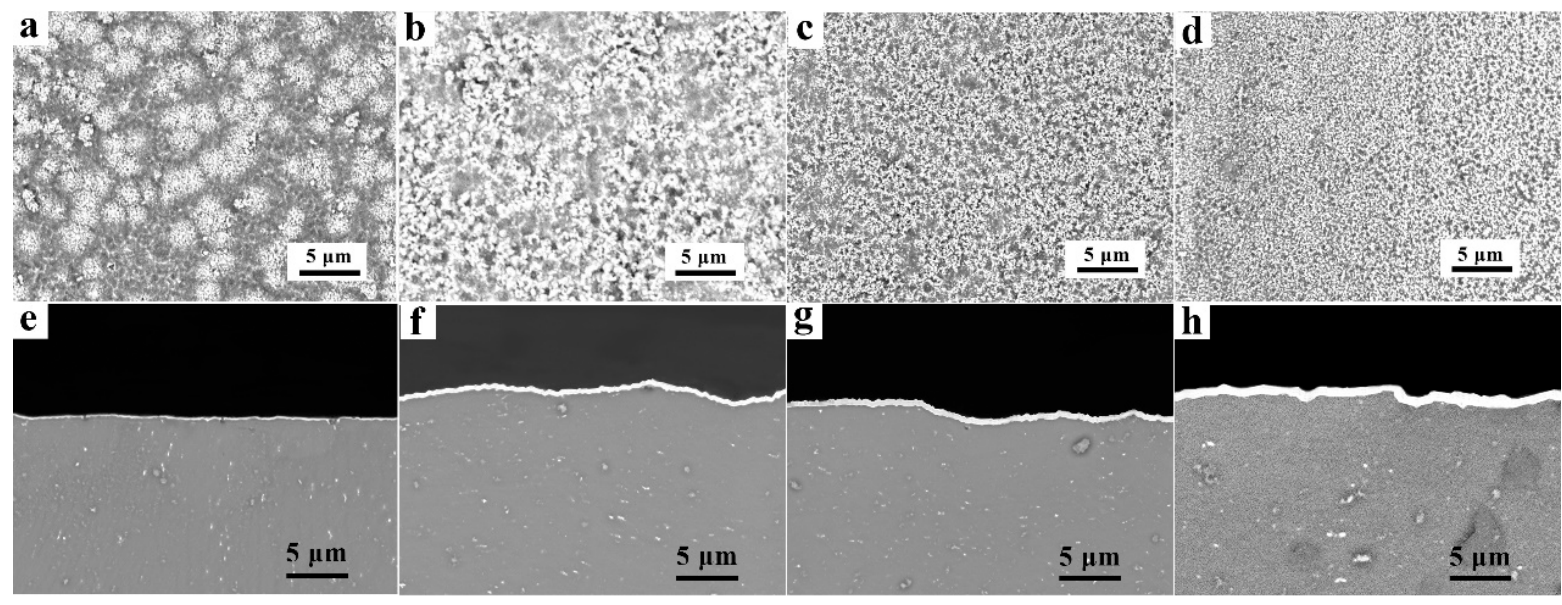

Figure 1. (a-d) The SEM planar view and (e-h) the cross-sectional morphologies of the Zn layers on the AZ91D Mg alloys with $\mathrm{Zn}$ immersion for (a,e) $2 \mathrm{~min},(\mathbf{b}, \mathbf{f}) 4 \mathrm{~min},(\mathbf{c}, \mathbf{g}) 6 \mathrm{~min}$, and (d,h) $8 \mathrm{~min}$.

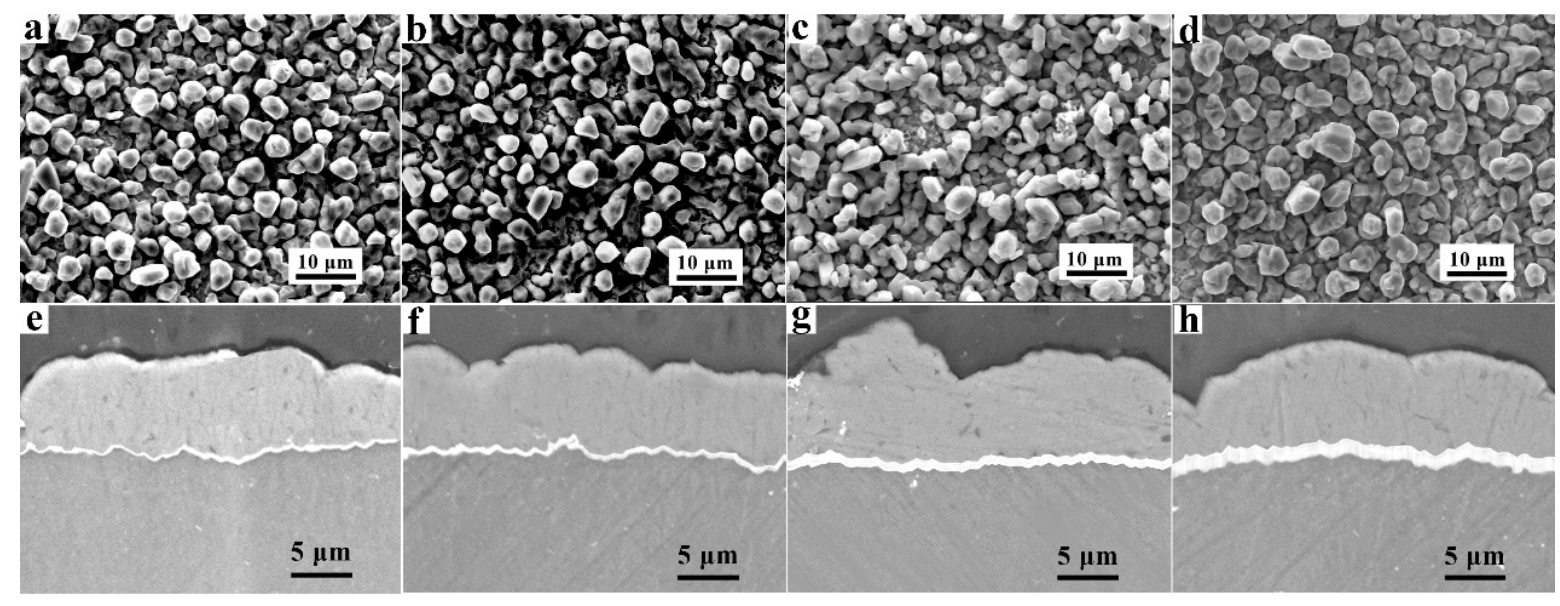

Figure 2. (a-d) The SEM planar view and (e-h) the cross-sectional morphologies of the Al coatings on the AZ91D Mg alloy with $\mathrm{Zn}$ immersion for (a,e) $2 \mathrm{~min},(\mathbf{b}, \mathbf{f}) 4 \mathrm{~min},(\mathbf{c}, \mathbf{g}) 6 \mathrm{~min}$, and (d,h) $8 \mathrm{~min}$.

Since the same amount of electric charge was applied during the process of Al electrodeposition, the thickness of the electrodeposition Al coatings obtained should be consistent. As shown in Figure $2 \mathrm{e}-\mathrm{h}$, the thickness of the electrodeposition Al coating obtained from the electrolyte with different $\mathrm{Zn}$ immersion times was almost identical, and the average thickness of the $\mathrm{Al}$ electrodeposits obtained was $7 \pm 3 \mu \mathrm{m}$. It is shown that with increasing $\mathrm{Zn}$ immersion times, the thickness of the $\mathrm{Zn}$ layers reasonably increased. The thickness of the $\mathrm{Zn}$ layers varied from $0.2 \mu \mathrm{m}$ to $1.8 \mu \mathrm{m}$, which is in accordance with the results in Figure 1. In addition, there were no gaps between the Al coatings and the $\mathrm{Zn}$ layer, or between the $\mathrm{Zn}$ layer and the substrate. It is indicated that the electrodeposited $\mathrm{Al}$ coating, $\mathrm{Zn}$ layer, and the Mg alloy substrate exhibited good interfacial bonding.

To further confirm the composition of the sandwich structure, Energy Dispersive X-Ray Spectroscopy (EDXS) analysis was carried out on the interfaces of the Al coating on the AZ91D Mg alloy with $\mathrm{Zn}$ immersion, and the typical results are shown in Figure 3. The line profiles of these elements were superimposed onto the SEM micrograph. The EDXS mappings show that $\mathrm{Al}, \mathrm{Zn}$, and $\mathrm{Mg}$ were distributed throughout the top, middle, and bottom layers of the sandwich structure, respectively. 


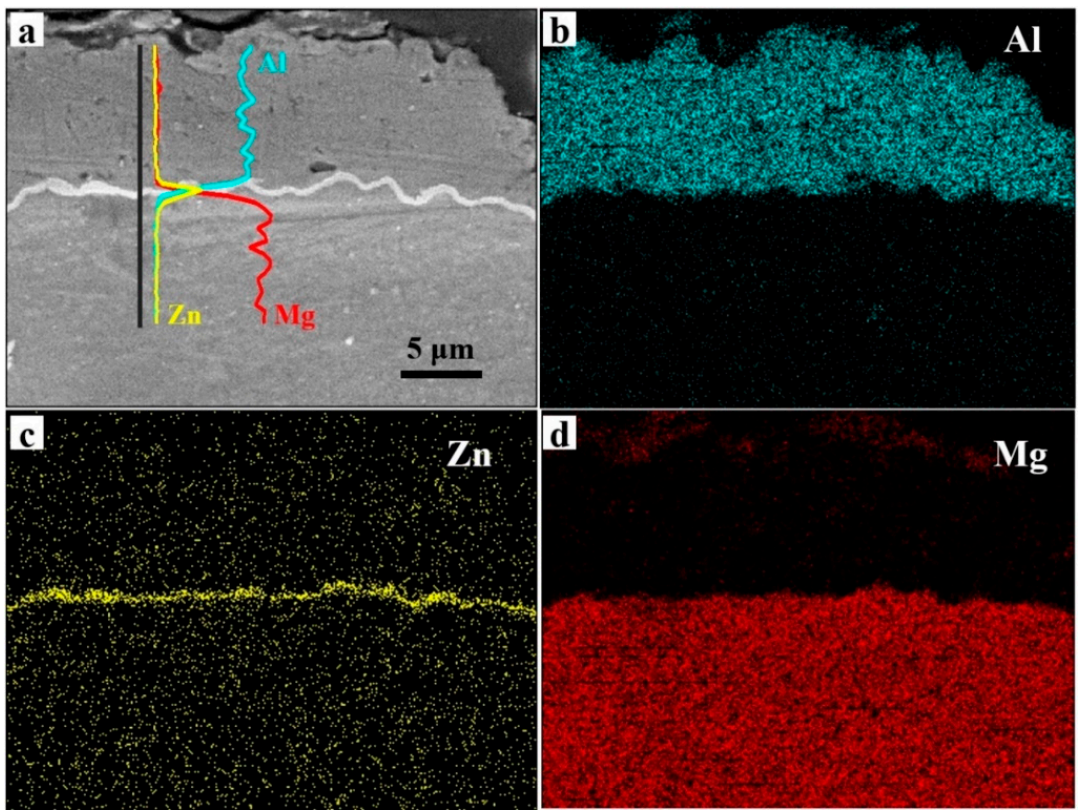

Figure 3. The Energy Dispersive X-Ray Spectroscopy (EDXS) analysis of the electrodeposition Al coatings obtained on the AZ91D Mg alloy with Zn immersion, (a) the cross-sectional morphology, (b-d) the EDXS analysis.

To identify the composition and phase structure, XRD analysis was carried out on the $\mathrm{Al}$ coating of the samples, and the typical XRD patterns of the electrodeposition $\mathrm{Al}$ coatings are shown in Figure 4. The strong diffraction peaks could be indexed to the Al coatings, $\mathrm{Zn}$ layer, and the $\mathrm{Mg}$ alloy substrate, respectively. The peaks of the Al coatings are associated with (200), (220), and (311) planes of its face-centered cubic structure, confirming the formation of a metallic and pure Al. The diffraction signals from the $\mathrm{Zn}$ layer and the substrate were also detected, due to the thinness of the Al coating and Zn dipping film. The peaks of $\mathrm{Mg}$ had the strongest intensity because the $\mathrm{Zn}$ layer and $\mathrm{Al}$ coatings were not thick enough.

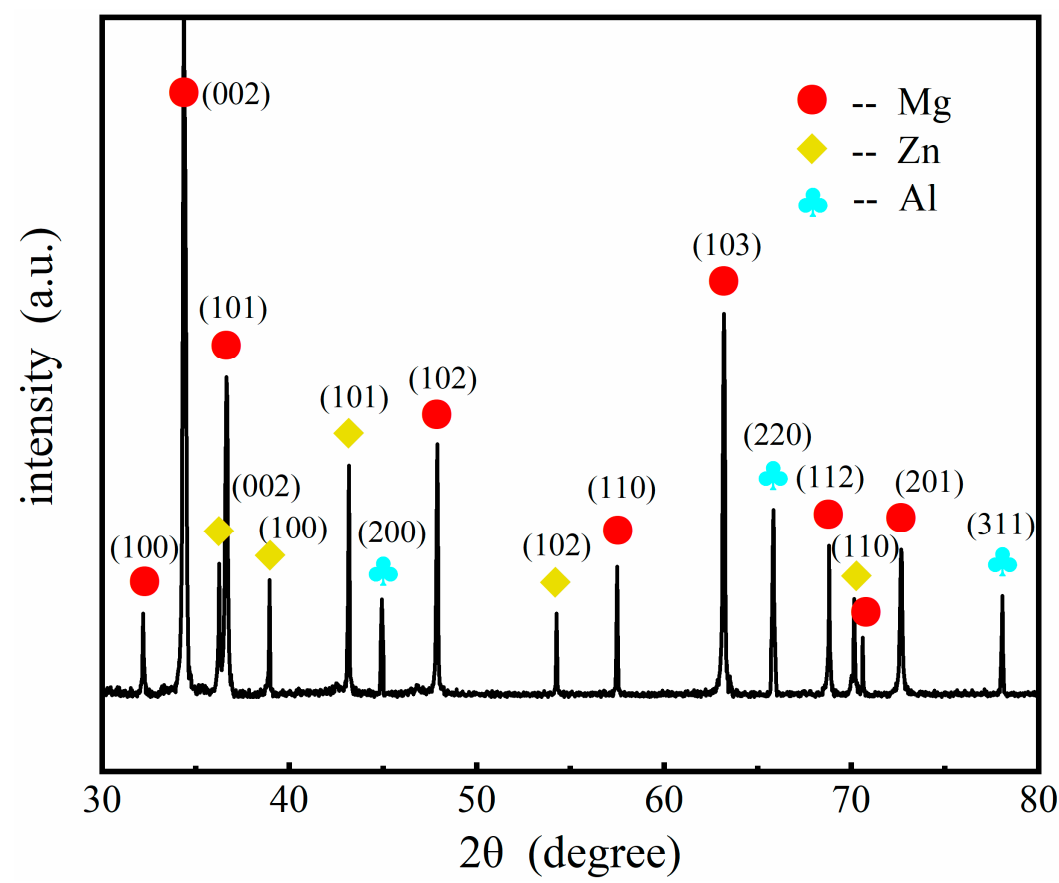

Figure 4. The typical XRD patterns of the electrodeposition Al coatings obtained on the AZ91D $\mathrm{Mg}$ alloy. 


\subsection{Microstructures after Heat Treatment}

Figure 5a-d shows the planar view SEM images of the Al coating on the Zn-immersed AZ91D alloys after heat treatment of $350{ }^{\circ} \mathrm{C}$ for $4 \mathrm{~h}$. The surface morphology of the $\mathrm{Al}$ coating transformed from particle-like (Figure 2) to a flat shape after heat treatment. Some tiny pinholes, formed during the heat treatment, were observed and circled in the planar view SEM images. The outer layer of the coatings was porous and thus, the inner layer could participate in corrosion processes, affecting the performance of corrosion resistance. The surface morphologies of the Al coating remained unchanged with the increase of the $\mathrm{Zn}$ immersion time. Figure 5e-h demonstrates the cross-sectional morphologies of the Zn-immersed AZ91D Mg alloys with $\mathrm{Al}$ coating after heat treatment. The major change in appearance was the variation of the $\mathrm{Zn}$ layer from a thin white to a thick grey one. Clearly, the inter-diffusion of the elements indeed occurred across the interface, indicating that the metallurgic bonding might be formed during the heat treatment process [24].

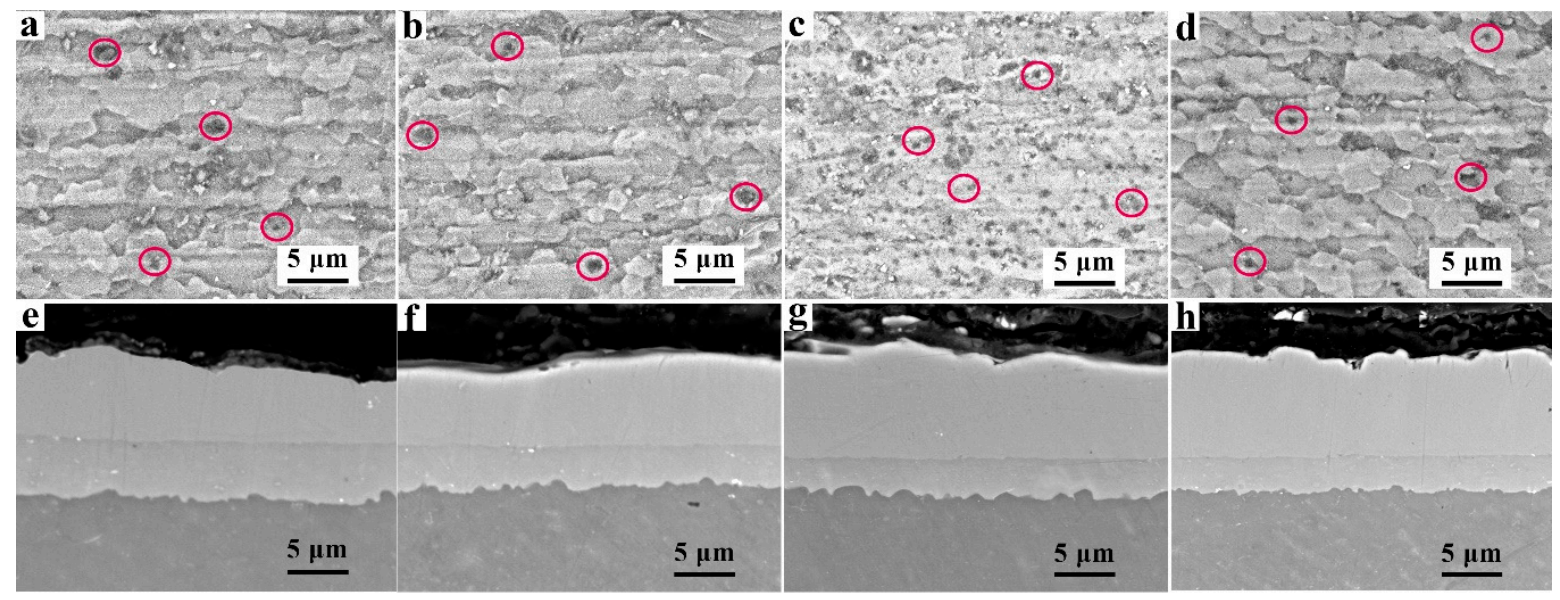

Figure 5. The SEM planar view and (e-h) the cross-sectional morphologies of the $\mathrm{Al}$ coating after $350{ }^{\circ} \mathrm{C}$ heat treatment for $4 \mathrm{~h}$ with $\mathrm{Zn}$ immersion for (a,e) $2 \mathrm{~min},(\mathbf{b}, \mathbf{f}) 4 \mathrm{~min},(\mathbf{c}, \mathbf{g}) 6 \mathrm{~min}$, and (d,h) $8 \mathrm{~min}$.

The observed variation of the $\mathrm{Al}$ coating and $\mathrm{Zn}$ layer might be ascribed to the phase transformation near the interface, which was generally induced by the heat treatment [12]. To understand in-depth the crystallinity evolution, the heat-treated samples with $\mathrm{Zn}$ immersion for $8 \mathrm{~min}$ were examined. Figure $6 \mathrm{a}$ demonstrates the overall crosssectional morphologies of the sample, in which the EDXS areas and the Electron Backscatter Diffraction (EBSD) region were marked. The EDXS mappings of the selected region in Figure 6a are shown in Figure 6c-e, and the EDXS spot analysis of the samples is shown in Table 2. As shown, the $\mathrm{Mg} / \mathrm{Al}$ atomic ratios of the two layers were approximately $41: 59$ and 57:40, respectively. As a result, the phases could be identified as $\gamma$-phase $\left(\mathrm{Mg}_{2} \mathrm{Al}_{3}\right)$ in the surface layer, and $\beta$-phase $\left(\mathrm{Mg}_{17} \mathrm{Al}_{12}\right)$ in the middle layer, respectively. Correspondingly, the EBSD inverse pole figure (IPF) map shown in Figure $6 \mathrm{~b}$ also indicates that the surface was composed of $\mathrm{Mg}_{2} \mathrm{Al}_{3}$, and the middle layer was composed of $\mathrm{Mg}_{17} \mathrm{Al}_{12}$.

The composition of the samples was further verified by the XRD pattern, as presented in Figure 7. Apart from the Mg alloy substrate, $\gamma$-phase and $\beta$-phase were also identified in the XRD pattern. Consequently, the double-layer coatings consisted of $\beta$-phase $\left(\mathrm{Mg}_{17} \mathrm{Al}_{12}\right)$ and $\gamma$-phase $\left(\mathrm{Mg}_{2} \mathrm{Al}_{3}\right)$.

After heat treatment, Zn could be detected in the energy spectrum (shown in Figure 6e), but no intermetallic compounds containing $\mathrm{Zn}$ were formed. The intermetallic compounds formed with the $\mathrm{Zn}$ layer after heat treatment had the same composition and structure as those formed without $\mathrm{Zn}$ addition. It indicated that, as a transition layer, $\mathrm{Zn}$ could not change the formation of $\beta$-phase $\left(\mathrm{Mg}_{17} \mathrm{Al}_{12}\right)$ and $\gamma$-phase $\left(\mathrm{Mg}_{2} \mathrm{Al}_{3}\right)$. A probable reason is that $\mathrm{Zn}$ functioned as a solute and diffused into aluminum. 


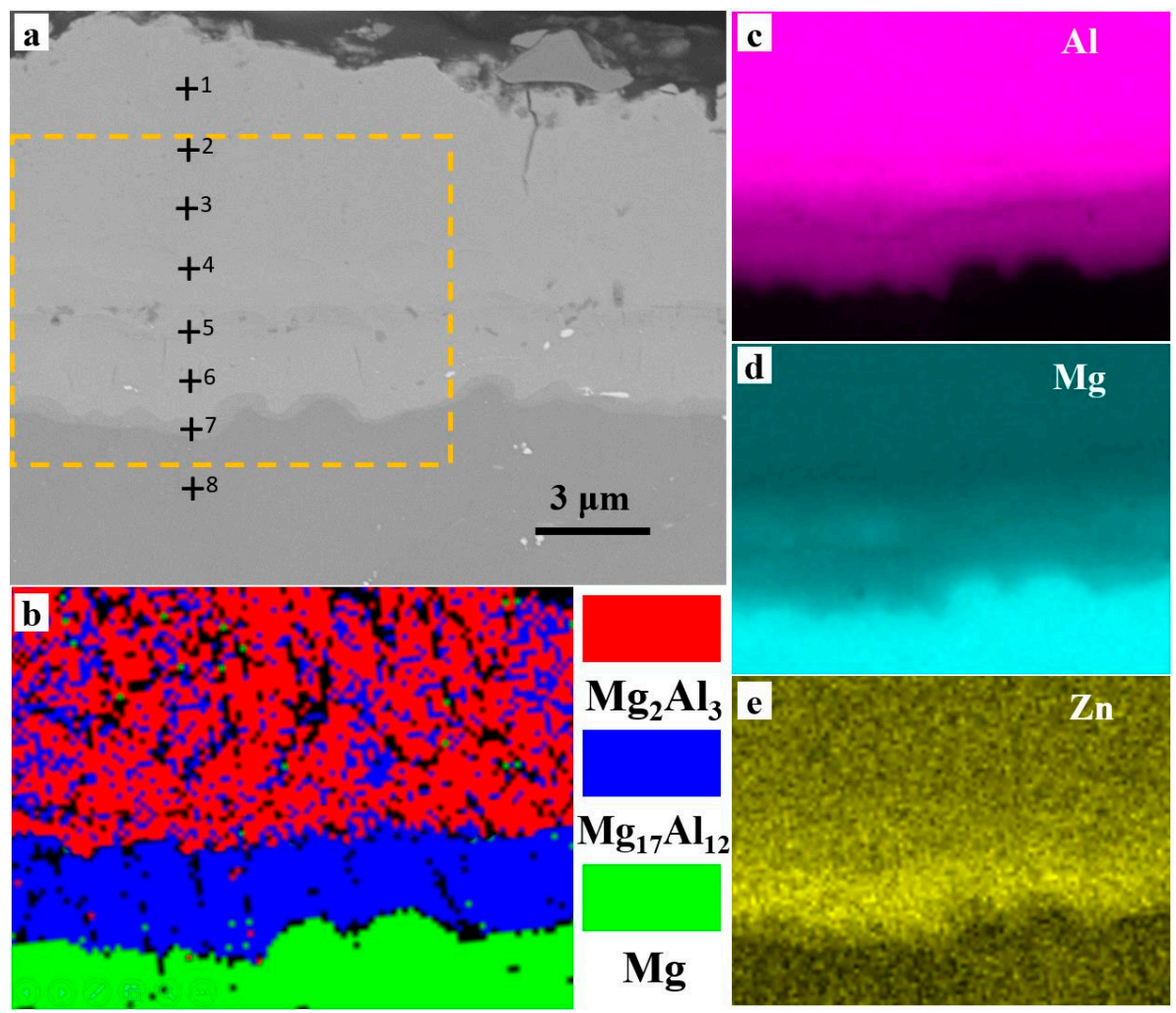

Figure 6. The Electron Backscatter Diffraction (EBSD) and the EDXS analysis of the Al coating after a $350{ }^{\circ} \mathrm{C}$ heat treatment for $4 \mathrm{~h}$. (a) the cross-sectional morphology, (b) EBSD analysis, (c-e) the EDXS analysis.

Table 2. The EDXS of the $\mathrm{Al}$ coating after $350{ }^{\circ} \mathrm{C}$ heat treatment for $4 \mathrm{~h}$.

\begin{tabular}{ccccccc}
\hline Point & Al wt. $\%$ & Zn wt. $\%$ & Mg wt. $\%$ & Al at. $\%$ & Zn at. $\%$ & Mg at. $\%$ \\
\hline 1 & 62.1 & 0.0 & 37.9 & 59.3 & 0.0 & 40.7 \\
2 & 61.9 & 0.0 & 38.1 & 59.1 & 0.0 & 40.9 \\
3 & 61.3 & 0.0 & 38.8 & 58.4 & 0.0 & 41.6 \\
4 & 61.1 & 0.0 & 38.9 & 58.3 & 0.0 & 41.7 \\
5 & 39.8 & 0.9 & 59.3 & 41.4 & 2.8 & 55.8 \\
6 & 36.9 & 1.5 & 61.6 & 38.5 & 3.7 & 57.8 \\
7 & 0.0 & 0.0 & 100.0 & 0.0 & 0.0 & 100.0 \\
8 & 0.0 & 0.0 & 100.0 & 0.0 & 0.0 & 100.0 \\
\hline
\end{tabular}

It has been confirmed that the $\mathrm{Mg} / \mathrm{Al}$ intermetallic compound coatings enriched with $\beta$-phase $\left(\mathrm{Mg}_{17} \mathrm{Al}_{12}\right)$ and $\gamma$-phase $\left(\mathrm{Mg}_{2} \mathrm{Al}_{3}\right)$ had already been prepared. According to the measurements in Figure 5, the thickness variations of the intermetallic compounds $\beta$-phase $\left(\mathrm{Mg}_{17} \mathrm{Al}_{12}\right)$ and $\gamma$-phase $\left(\mathrm{Mg}_{2} \mathrm{Al}_{3}\right)$ with various $\mathrm{Zn}$ immersion times are shown in Figure 8. The thicknesses of the double-layer coating of the samples with $\mathrm{Zn}$ immersion for $2 \mathrm{~min}, 4 \mathrm{~min}, 6 \mathrm{~min}$, and $8 \mathrm{~min}$ were almost the same, approximately $7 \pm 1 \mu \mathrm{m}$. However, there was a significant difference in the composition of the two compounds. When the $\mathrm{Zn}$ immersion time was $2 \mathrm{~min}$, the thickness of the obtained $\mathrm{Zn}$ layer was $0.2 \mu \mathrm{m}$, and the ratio of the $\gamma$-phase and $\beta$-phase, determined by the thickness in the cross-sectional morphologies, was approximately 1:1. With the increase of the thickness of the $\mathrm{Zn}$ layer, the proportion of the $\gamma$-phase increased, while that of $\beta$-phase decreased. When the thickness of the $\mathrm{Zn}$ layer reached $1.8 \mu \mathrm{m}$, the ratio of the $\gamma$-phase and $\beta$-phase was approximately 4:1. 


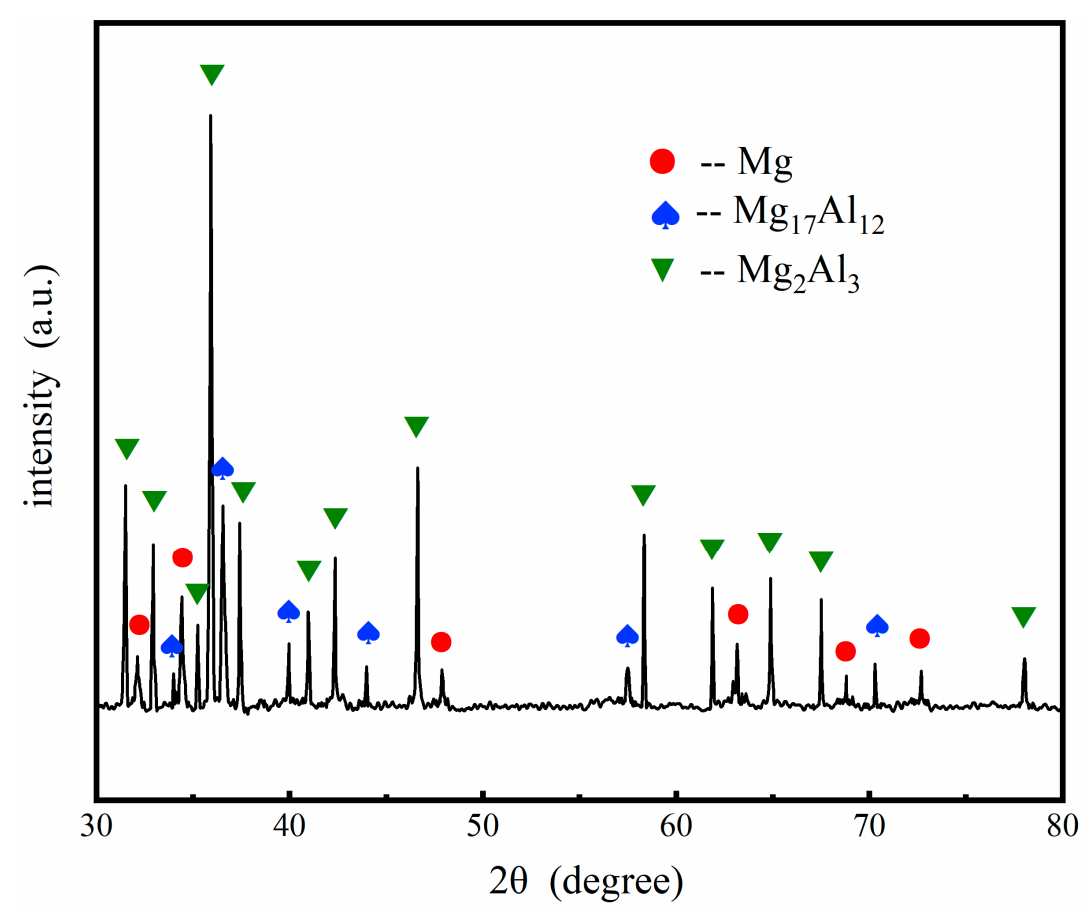

Figure 7. The typical XRD patterns of the $\mathrm{Al}$ coating after $350{ }^{\circ} \mathrm{C}$ heat treatment for $4 \mathrm{~h}$.

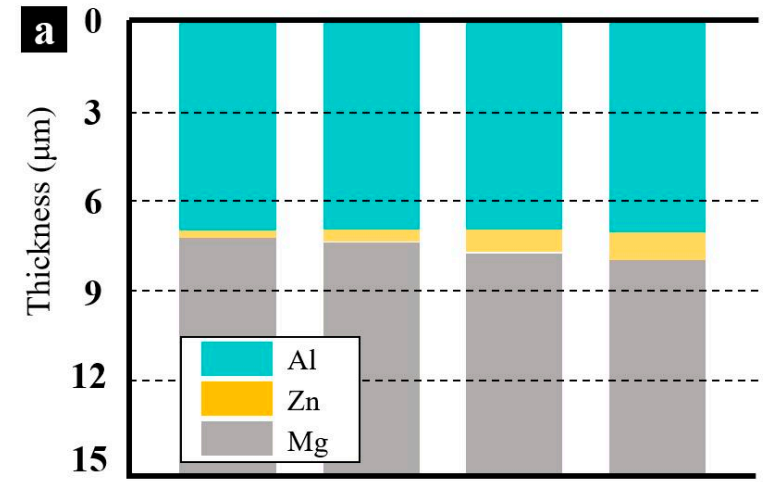

(I) (II)

(III)

(IV)

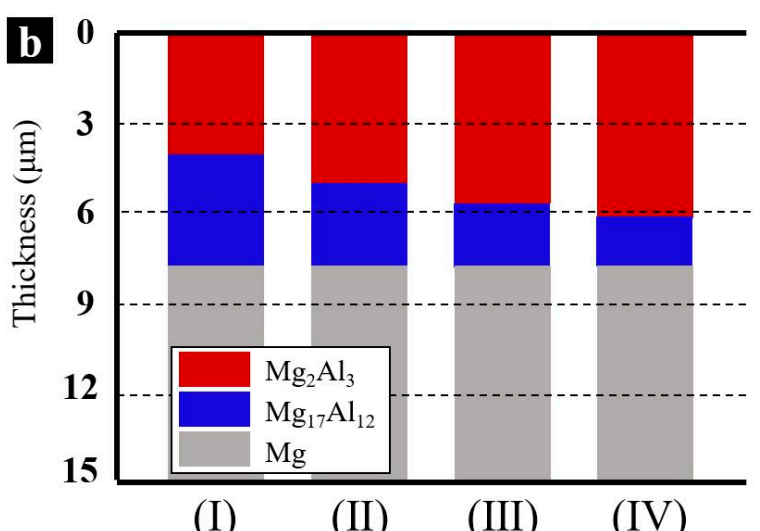

Figure 8. The thickness variations of the intermetallic compounds $\beta$-phase $\left(\mathrm{Mg}_{17} \mathrm{Al}_{12}\right)$ and $\gamma$-phase $\left(\mathrm{Mg}_{2} \mathrm{Al}_{3}\right)$ with various Zn immersion times (I) $2 \mathrm{~min}$, (II) $4 \mathrm{~min}$, (III) $6 \mathrm{~min}$, and (IV) $8 \mathrm{~min}$. (a) electrodeposition Al coatings obtained on the AZ91D $\mathrm{Mg}$ alloy, (b) the $\mathrm{Al}$ coatings after a $350{ }^{\circ} \mathrm{C}$ heat treatment for $4 \mathrm{~h}$.

The variations of the thickness of the $\mathrm{Zn}$ layer made the main contribution to the different ratios of the two $\mathrm{Mg} / \mathrm{Al}$ intermetallic compounds. The $\mathrm{Zn}$ layer played a predominant role in inhibiting the inter-diffusion between the $\mathrm{Mg}$ and $\mathrm{Al}$. As the $\mathrm{Zn}$ layer was as thin as $0.4 \mu \mathrm{m}$, it appeared porous and non-uniform (as shown in Figure 1). The inter-diffusion, especially from the $\mathrm{Mg}$ substrate to $\mathrm{Al}$, was abundant and sufficient, so the $\beta$-phase, which was enriched with $\mathrm{Mg}$, was preferentially formed. When the thickness of the $\mathrm{Zn}$ layer was $1.8 \mu \mathrm{m}$, it became thick and dense, which made the diffusion process more difficult. After heat treatment, the $\mathrm{Mg}$ content decreased. As a result, only a little $\beta$-phase was formed and the majority of the $\mathrm{Mg} / \mathrm{Al}$ intermetallic compounds were $\gamma$-phase.

\subsection{Nanomechanical Coating Properties}

The nanomechanical behaviors of the $\mathrm{Zn}$ layers and $\mathrm{Al}$ coatings before and after heat treatment were evaluated by nanoindentation tests. The load-displacement curves of the samples obtained from the nanoindentation tests are shown in Figure 9. For comparison, 
the mechanical properties of the AZ91D Mg substrate were also tested. The nano-hardness and the elastic modulus determined by the load-displacement are listed in Table 3.
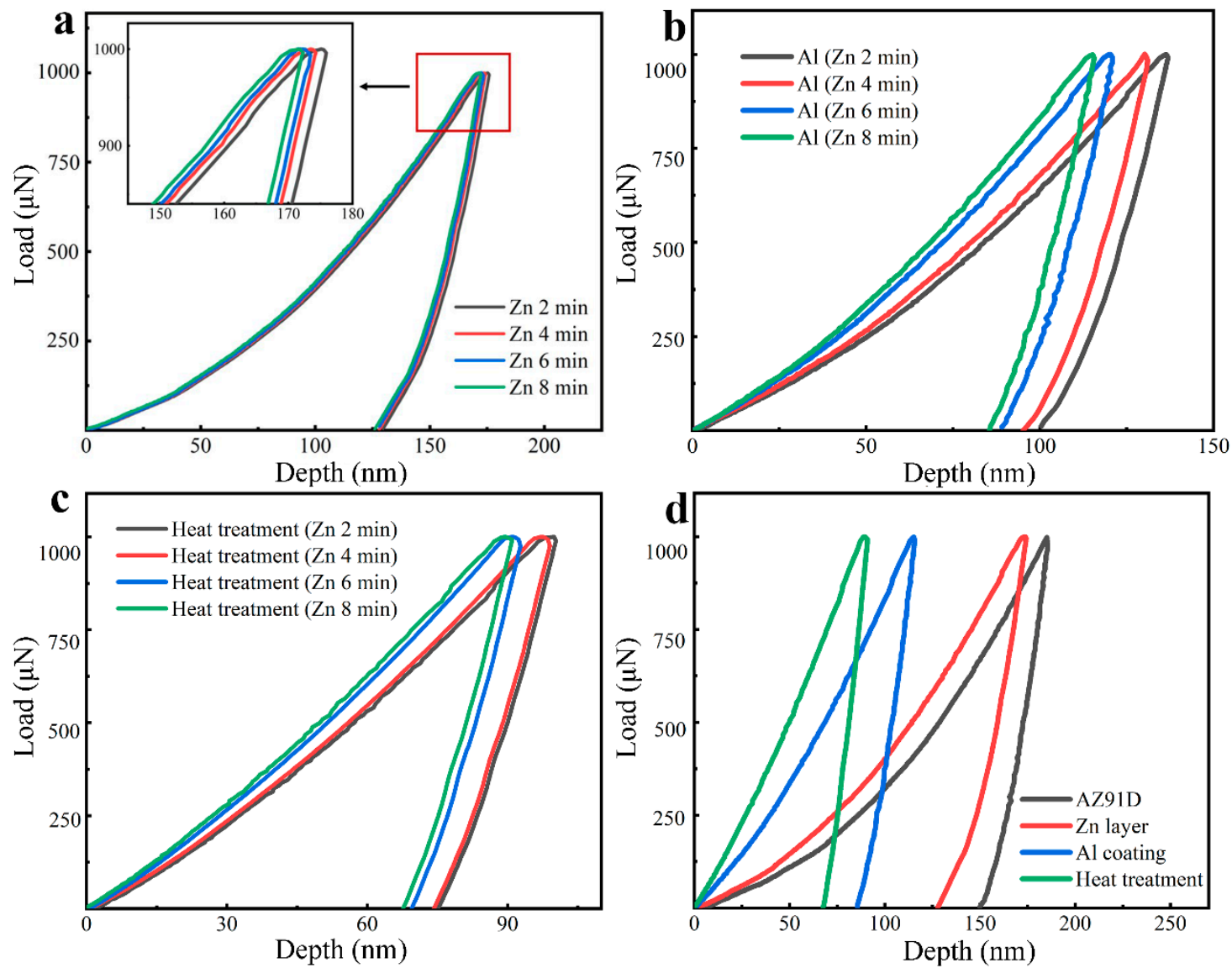

Figure 9. Load-displacement curves obtained from the nanoindentation tests on (a) Zn layers (insert is the larger drawing of the rectangular framed region), (b) Al coatings, (c) Al coatings after heat treatment, and (d) the comparison of the load-displacement curves of the AZ91D substrate, the Zn-immersed, the Al-coated, and the heat-treated samples.

Table 3. The nanomechanical properties of the AZ91D substrate, the $\mathrm{Zn}$ film, the $\mathrm{Al}$ coating, $\beta$-phase $\left(\mathrm{Mg}_{17} \mathrm{Al}_{12}\right)$ and $\gamma$-phase $\left(\mathrm{Mg}_{2} \mathrm{Al}_{3}\right)$.

\begin{tabular}{|c|c|c|c|c|c|c|}
\hline Unit & AZ91D & - & Zn & Al & $\begin{array}{c}\beta \text {-Phase } \\
\left(\mathbf{M g}_{17} \mathbf{A l}_{12}\right)\end{array}$ & $\begin{array}{c}\gamma \text {-Phase } \\
\left(\mathrm{Mg}_{2} \mathrm{Al}_{3}\right)\end{array}$ \\
\hline \multirow{4}{*}{ nHV (GPa) } & \multirow{4}{*}{$1.12 \pm 0.09$} & $\mathrm{Zn} 2 \mathrm{~min}$ & $1.40 \pm 0.04$ & $2.35 \pm 0.06$ & $3.51 \pm 0.05$ & $3.49 \pm 0.10$ \\
\hline & & $\mathrm{Zn} 4 \mathrm{~min}$ & $1.45 \pm 0.02$ & $2.40 \pm 0.08$ & $3.55 \pm 0.04$ & $3.52 \pm 0.08$ \\
\hline & & $\mathrm{Zn} 6 \mathrm{~min}$ & $1.53 \pm 0.05$ & $2.41 \pm 0.07$ & $3.56 \pm 0.04$ & $3.57 \pm 0.07$ \\
\hline & & Zn 8 min & $1.57 \pm 0.03$ & $2.44 \pm 0.06$ & $3.58 \pm 0.06$ & $3.59 \pm 0.08$ \\
\hline \multirow{4}{*}{ EIT (GPa) } & \multirow{4}{*}{$40.20 \pm 8.40$} & $\mathrm{Zn} 2 \mathrm{~min}$ & $49.72 \pm 0.03$ & $66.73 \pm 0.05$ & $65.91 \pm 0.08$ & $63.15 \pm 0.06$ \\
\hline & & $\mathrm{Zn} 4 \mathrm{~min}$ & $51.54 \pm 0.04$ & $67.51 \pm 0.06$ & $66.32 \pm 0.07$ & $63.89 \pm 0.05$ \\
\hline & & Zn 6 min & $52.71 \pm 0.04$ & $67.76 \pm 0.05$ & $66.67 \pm 0.06$ & $64.28 \pm 0.08$ \\
\hline & & $\mathrm{Zn} 8 \mathrm{~min}$ & $55.31 \pm 0.02$ & $68.25 \pm 0.07$ & $66.78 \pm 0.06$ & $64.81 \pm 0.06$ \\
\hline
\end{tabular}

Figure 9a shows the load-displacement curves of the AZ91D substrate immersed in $\mathrm{Zn}$ with different times. There was a little discrepancy among the curves. This was attributed to the increased thickness of the $\mathrm{Zn}$ layer, which can resist more deformation than the AZ91D substrate under loading [25]. Figure $9 \mathrm{~b}$ depicts that the nano-hardness of the $\mathrm{Al}$ coatings obtained via electrodeposition increased obviously with the increase of the thickness of $\mathrm{Zn}$ layers. This means that the nano-hardness of the Al coatings was highly related to the thickness of the $\mathrm{Zn}$ layer. Notice that in Figure 9c, the nano-hardness of the 
intermetallic compound layers formed after heat treatment also increased significantly with the increase of the thickness of the $\mathrm{Zn}$ layers. The nano-hardness of the intermetallic compounds could be controlled by adjusting the thickness of the $\mathrm{Zn}$ layer. Compared with the average nano-hardness of the AZ91D alloy, the Zn layer, the Al coating, and the intermetallic compounds (shown in Figure 9d) after the electrodeposition and heat treatment, the reinforcement in nano-hardness appeared very significant. The elastic modulus and the nano-hardness determined by the curves also increased with the $\mathrm{Zn}$ immersion time increases (Table 3), which proves that varying the thickness of the Zn layer can tune the nanomechanical properties of the $\mathrm{Mg} / \mathrm{Al}$ intermetallic compounds.

In addition, after heat treatment, the variations of the elastic modulus and nanohardness among the samples were more pronounced, which increased with increasing the $\mathrm{Zn}$ immersion time. Such an enhancement was due to the phase transformation and the strengthening effect of the $\beta$-phase after heat treatment, as abovementioned [26]. Generally, the second phases, $\beta$-phase and $\gamma$-phase, were believed to be harder than the Al coating and $\mathrm{Zn}$ film, and the $\beta$-phase was softer than the $\gamma$-phase $[17,27]$. The experiment results in this paper also give evidence to this conclusion. In the intermetallic compound layers, it can be assumed that the $\gamma$-phase and $\beta$-phase played equal roles in hardness. According to the volume percentage of these two phases, an average hardness could be calculated, which was approximately three times higher than that of the AZ91D substrate.

Overall, both the $\mathrm{Zn}$ layer and Al coating could enhance the nanomechanical properties of AZ91D. Also, the second phase formed by heat treatment can lead to further improvement. Admittedly, hardness is not a perfect measure of wear resistance, nor, in fact, is any single wear test since the wear of a given material may vary substantially depending on the mode of wear. However, in this work, since the requirement for a specific method of wear resistance is absent, hardness could also be taken as a generic measure of abrasion, scratch, and wear resistance. As a result, the increase of hardness implies that the mechanical and wear resistance of the Al coating was improved effectively.

\subsection{Hydrogen Evolution Tests}

Figure 10 shows the typical representation of the hydrogen evolution rate of the studied samples with increasing $\mathrm{Zn}$ immersion times in $3.5 \mathrm{wt}$.\% $\mathrm{NaCl}$ solution. It can be seen from Figure 10a,b that as the $\mathrm{Zn}$ immersion time increased, there was no positive correlation between zinc dipping time and the amount and rate of hydrogen evolution. The results of the hydrogen evolution tests of the $\mathrm{Zn}$ layers and Al coatings exhibited no clear relationship with the $\mathrm{Zn}$ immersion times. A probable reason for this is that different corrosion protection mechanisms may have been involved in the Zn layers and Al coatings. After heat treatment, as shown in Figure 10c, the hydrogen evolution curves can be approximately considered as straight lines, which demonstrates that the corrosion of the intermetallic compounds shared the same mechanism. The amount of hydrogen generated by the corrosion of the $\mathrm{Mg}$ alloys increased with the increase in $\mathrm{Zn}$ immersion times, namely, with the increase of the ratio of the $\gamma$-phase and $\beta$-phase. It is indicated that the intermetallic compounds prepared by $2 \mathrm{~min} \mathrm{Zn}$ immersion, which contained the most $\beta$-phase $\left(\mathrm{Mg}_{17} \mathrm{Al}_{12}\right)$, were the least prone to corrosion in $\mathrm{NaCl}$ solutions.

For clarity, the comparison of the hydrogen evolution rates for the AZ91D substrate, the $\mathrm{Zn}$-immersed, the Al-coated, and the heat-treated samples are shown in Figure 10d. The hydrogen evolution rate of the $\mathrm{Zn}$ layer sample was higher compared with that of the AZ91 substrate due to poor corrosion performance [28]. Meanwhile, the Al-coated sample presented the lowest rate, revealing that the Al coating provided the protection for the AZ91D substrate. In fact, the measurement of hydrogen evolution depends not on the dissolution of $\mathrm{Al}$ but that of $\mathrm{Mg}$, since the cathodic reaction for $\mathrm{Mg}$ dissolution is responsible for hydrogen evolution [29]. Therefore, the dissolution of the substrate was suppressed by the $\mathrm{Al}$ coating. In addition, the hydrogen evolution rate of the heat-treated sample was slightly increased, indicating that the protection of the Al coating was undermined after heat treatment. The $\gamma$-phase that formed after heat treatment was believed to favor an 
oxygen reduction as the dominating cathodic reaction under the corrosion situation [19], and to be spontaneously passive in $3.5 \% \mathrm{NaCl}$ solution [30,31]. However, the fact was that the hydrogen evolution rate slightly increased after heat treatment. There are two key factors that could be responsible for the phenomenon. One is that $\gamma$-phase can only provide limited protection during long-term corrosion since it is not a very inherent corrosionresistant phase [19]. Another is that more $\mathrm{Mg}$ solutes were observed in the surface layer after heat treatment compared with the samples covered by electrodeposition Al coatings. Thus, it was inferred that the diffusion of $\mathrm{Mg}$ into the surface layer might lead to an increased rate, which can support water reduction as the cathodic reaction [32].
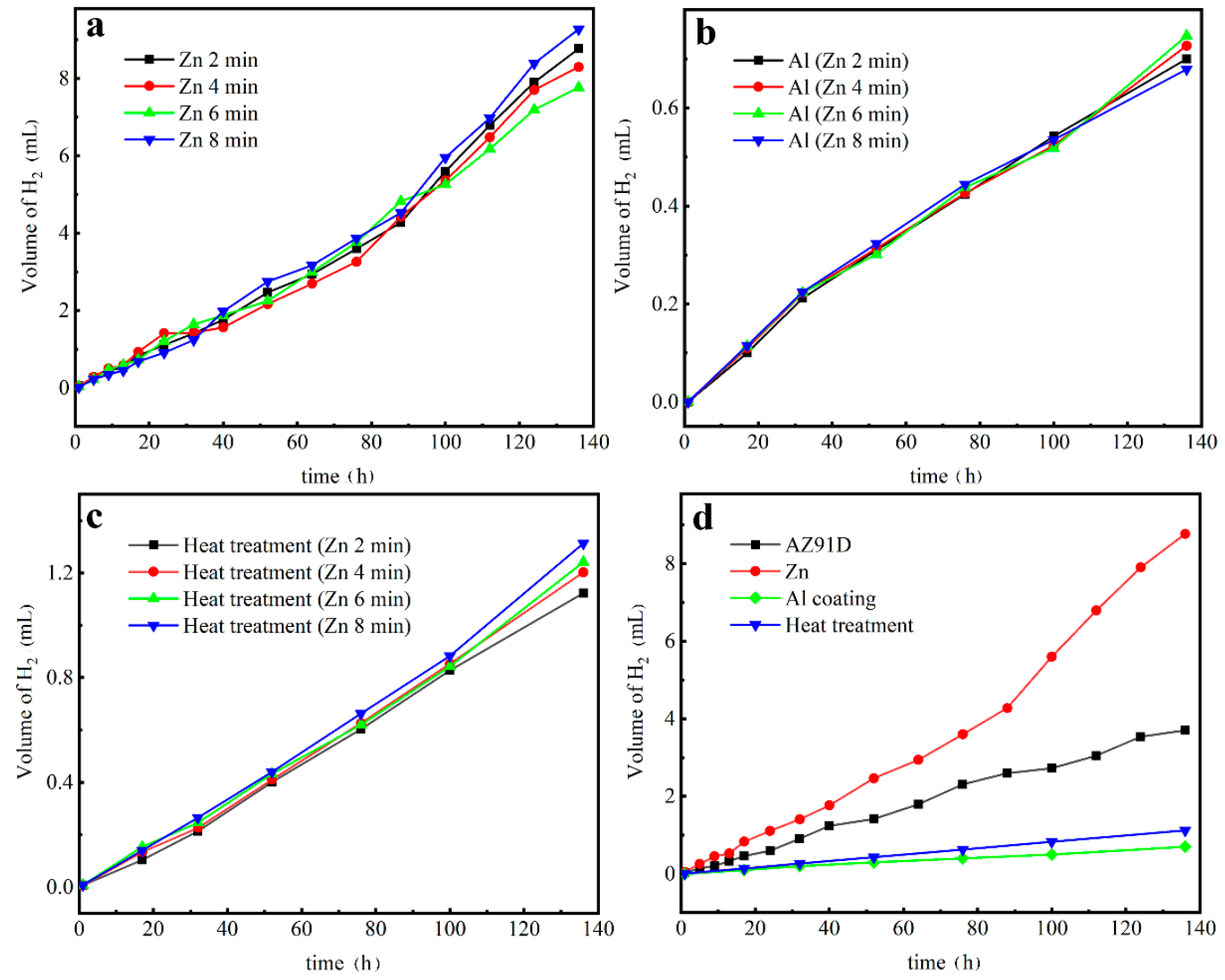

Figure 10. Hydrogen evolution curves for (a) Zn layers, (b) Al coatings, (c) Al coatings after heat treatment, and (d) the comparison of the curves of the AZ91D substrate, the Zn-immersed, the Al-coated, and the heat-treated samples.

\subsection{Potentiodynamic Testing}

Figure 11 shows the potentiodynamic polarization curves of the different studied samples; other detail parameters calculated by the Tafel extrapolation are summarized and shown in Table 4. Similarly, it can be seen that the corrosion current density $\left(\mathrm{i}_{\text {corr }}\right)$ and corrosion potential ( $\mathrm{E}_{\text {corr }}$ ) at the $\mathrm{OCP}$ of the $\mathrm{Zn}$ layers and the $\mathrm{Al}$ coatings did not appear to be regular changes as the $\mathrm{Zn}$ immersion times increased. In contrast, the $\mathrm{i}_{\text {corr }}$ of the $\mathrm{Mg} / \mathrm{Al}$ intermetallic compounds increased from $42.19 \mu \mathrm{A} \cdot \mathrm{cm}^{-2}$ to $60.57 \mu \mathrm{A} \cdot \mathrm{cm}^{-2}$, and the $\mathrm{E}_{\text {corr }}$ shifted towards the negative direction from $-1.35 \mathrm{~V}$ to $-1.41 \mathrm{~V}$ as the $\mathrm{Zn}$ immersion times increased from $2 \mathrm{~min}$ to $8 \mathrm{~min}$. The variations of the content of the different intermetallic compounds $\beta$-phase $\left(\mathrm{Mg}_{17} \mathrm{Al}_{12}\right)$ and $\gamma$-phase $\left(\mathrm{Mg}_{2} \mathrm{Al}_{3}\right)$, which were attributed to the control of the $\mathrm{Zn}$ immersion layer thickness, contributed to the difference in corrosion resistance. As the $\mathrm{Zn}$ immersion time increased, the $\mathrm{Zn}$ layers got thicker and the composition of the $\beta$-phase $\left(\mathrm{Mg}_{17} \mathrm{Al}_{12}\right)$ decreased but that of the $\gamma$-phase $\left(\mathrm{Mg}_{2} \mathrm{Al}_{3}\right)$ increased; as a result, the corrosion resistance declined gradually. The experimental results of the potentiodynamic testing were in accordance with those of the hydrogen evolution tests. 

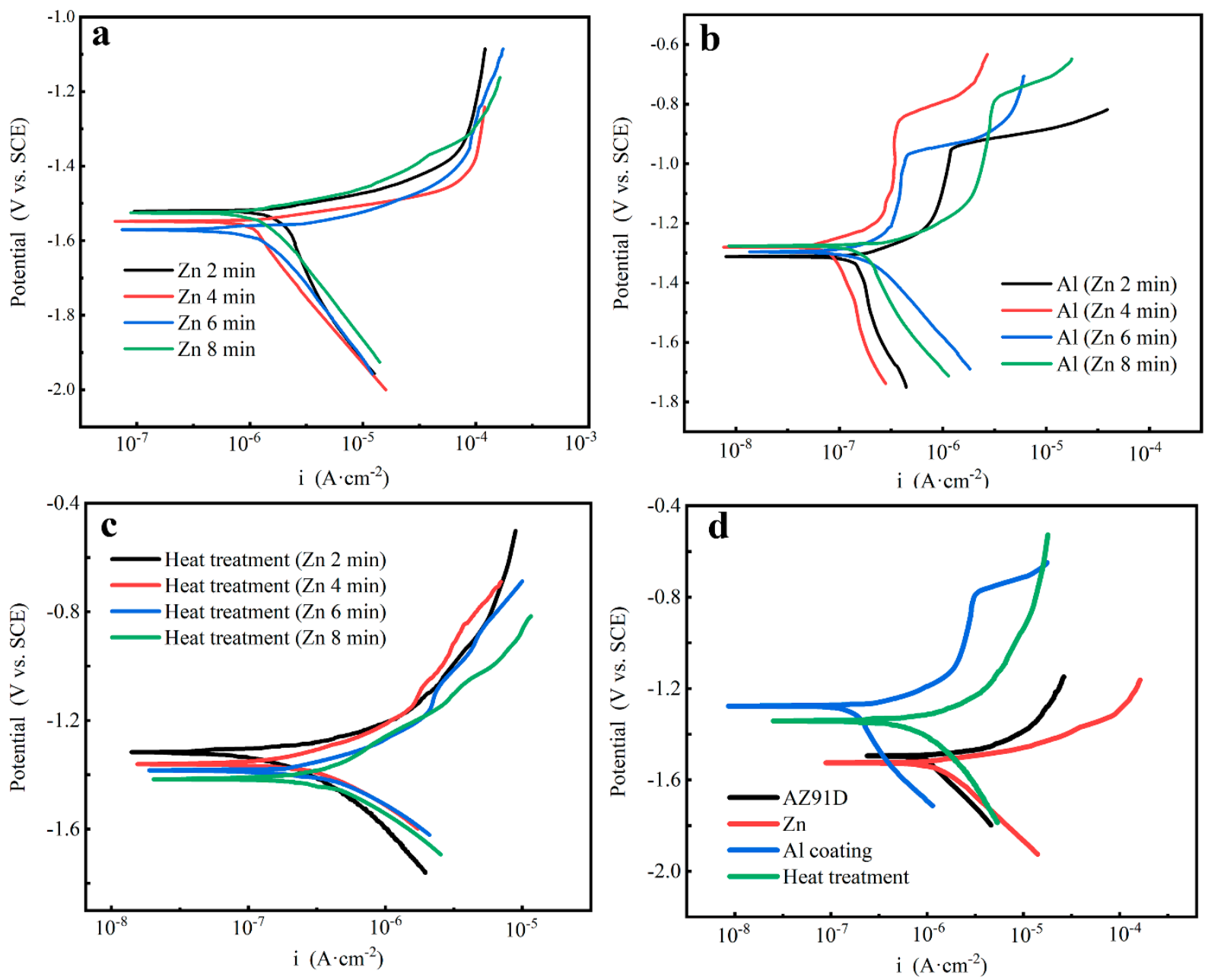

Figure 11. Potentiodynamic polarization curves of (a) the Zn layers, (b) the Al coatings, (c) the Al coatings after heat treatment, and (d) the comparison of the curves of the AZ91D substrate, the Zn-immersed, Al-coated, and the heattreated samples.

Table 4. Corrosion characteristics obtained by polarization in $3.5 \% \mathrm{NaCl}$ solution of the AZ91D, the $\mathrm{Zn}$ layers, the $\mathrm{Al}$ coatings, and the $\mathrm{Al}$ coatings after heat treatment.

\begin{tabular}{cccccc}
\hline Unit & AZ91D & $\begin{array}{c}\text { Zn layer } \\
\text { Zn 2 min }\end{array}$ & $\begin{array}{c}\text { Zn layer } \\
\text { Zn 4 min }\end{array}$ & $\begin{array}{c}\text { Zn layer } \\
\text { Zn 6 min }\end{array}$ & $\begin{array}{c}\text { Zn layer } \\
\text { Zn 8 min }\end{array}$ \\
\hline $\mathrm{E}_{\text {corr }}(\mathrm{V})$ & -1.51 & -1.52 & -1.55 & -1.56 & -1.52 \\
$\mathrm{i}_{\text {corr }}\left(\mu \mathrm{A} \cdot \mathrm{cm}^{-2}\right)$ & 103.81 & 125.18 & 118.07 & 120.90 & 122.52 \\
\hline \multirow{2}{*}{ Unit } & & Al-coated & Al-coated & Al-coated & Al-coated \\
& & Zn 2 min & Zn 4 min & Zn 6 min & Zn 8 min \\
\hline $\mathrm{E}_{\text {corr }}(\mathrm{V})$ & -1.31 & -1.27 & -1.29 & -1.27 \\
$\mathrm{i}_{\text {corr }}\left(\mu \mathrm{A} \cdot \mathrm{cm}^{-2}\right)$ & 35.79 & 33.44 & 41.38 & 37.49 \\
\hline & & Heat & Heat & Heat & Heat \\
Unit & & Treatment & Treatment & Treatment & Treatment \\
& & Zn 2 min & Zn 4 min & Zn 6 min & Zn 8 min \\
\hline $\mathrm{E}_{\text {corr }}(\mathrm{V})$ & -1.35 & -1.37 & -1.39 & -1.41 \\
$\mathrm{i}_{\text {corr }}\left(\mu \mathrm{A} \cdot \mathrm{cm}^{-2}\right)$ & & 42.19 & 49.90 & 55.67 & 60.57 \\
\hline
\end{tabular}

The typical samples after each process were selected, and the comparison of potentiodynamic polarization curves of different samples is shown in Figure $11 \mathrm{~d}$. The $\mathrm{i}_{\text {corr }}$ and the $\mathrm{E}_{\text {corr }}$ at the OCP of AZ91D were $103.81 \mu \mathrm{A} \cdot \mathrm{cm}^{-2}$ and $-1.51 \mathrm{~V}$, respectively. As the $\mathrm{Zn}$ 
layer was immersed in the $\mathrm{Mg}$ alloy matrix, the $\mathrm{i}_{\text {corr }}$ increased and the $\mathrm{E}_{\text {corr }}$ became more negative, indicating that the $\mathrm{Zn}$ layer could not protect the $\mathrm{Mg}$ alloy matrix. After the electrodeposition of $\mathrm{Al}$ coatings, the samples showed a polarization response of pure $\mathrm{Al}$, and remarkable passivation ranges were observed in the potentiodynamic polarization curves. A much lower free corrosion current density than the $\mathrm{Mg}$ alloy substrate confirmed that the electrodeposition $\mathrm{Al}$ coatings could improve corrosion resistance effectively. After heat treatment, the passivation behavior disappeared expectantly since the electrodeposition $\mathrm{Al}$ coatings were replaced by the intermetallic compounds $\beta$-phase $\left(\mathrm{Mg}_{17} \mathrm{Al}_{12}\right)$ and $\gamma$-phase $\left(\mathrm{Mg}_{2} \mathrm{Al}_{3}\right)$. The free corrosion current density increased slightly and a little negative shift occurred in the free corrosion potential compared with the electrodeposition $\mathrm{Al}$ coatings, demonstrating that there was little difference before and after heat treatment in corrosion resistance. However, the free corrosion current density of the heat-treated sample was still much smaller than that of the $\mathrm{Mg}$ alloy substrate. The experiment results of the potentiodynamic testing are consistent with the trend shown in the hydrogen evolution tests (Figure 10) and suggest that the corrosion resistance of the heat-treated samples was much better than that of the $\mathrm{Mg}$ alloy.

\subsection{Comprehensive Assessment}

According to the previous experimental results, the relationship between the thickness of the $\mathrm{Zn}$ layer and the mechanical performance of the obtained intermetallic compounds was established and is presented in Figure 12. The average nano-hardness value of the intermetallic compounds and the reciprocal value of the free corrosion current density were selected as the qualitative criteria of the mechanical properties and corrosion resistance. Figure 12 reflects the inter-relationship between the thickness of the Zn layer and the mechanical property and corrosion resistance of the $\mathrm{Mg} / \mathrm{Al}$ intermetallic compounds, qualitatively.

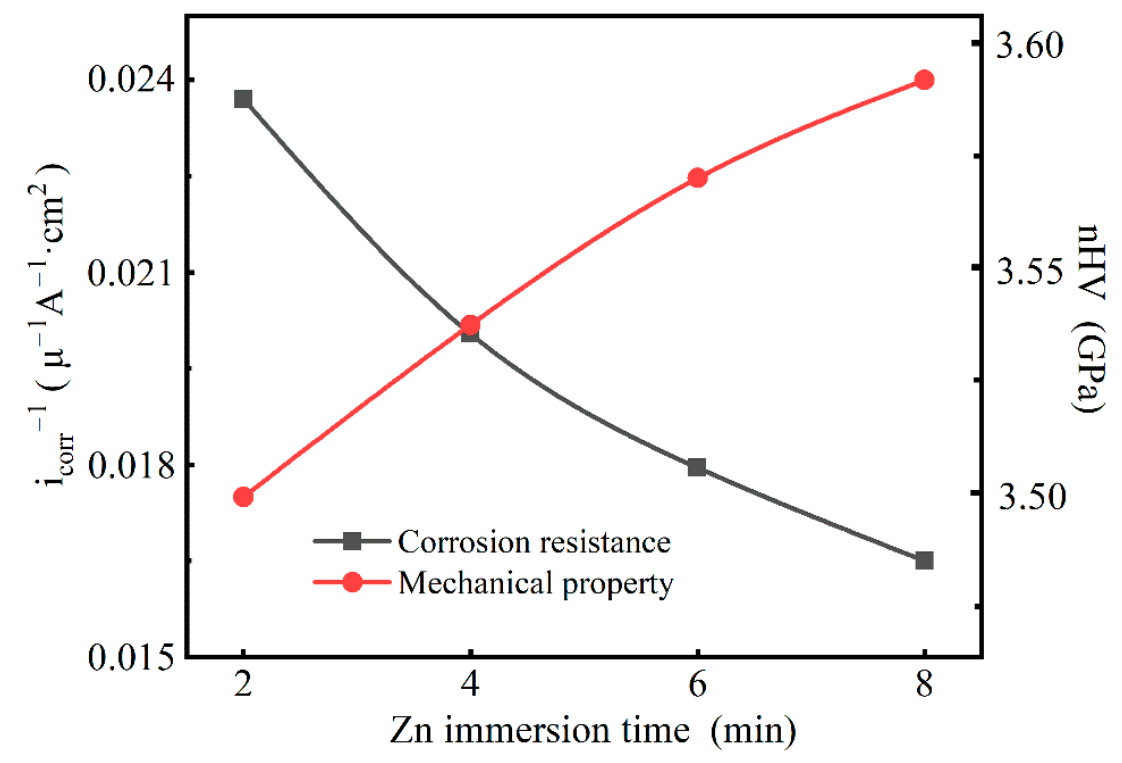

Figure 12. The qualitative mechanical property and corrosion resistance variation of the $\mathrm{Mg} / \mathrm{Al}$ intermetallic compounds $\beta$-phase $\left(\mathrm{Mg}_{17} \mathrm{Al}_{12}\right)$ and $\gamma$-phase $\left(\mathrm{Mg}_{2} \mathrm{Al}_{3}\right)$, with various $\mathrm{Zn}$ immersion times (I) Zn 2 min, (II) Zn 4 min, (III) Zn 6 min, and (IV) Zn 8 min.

It can be seen that with the increases in the $\mathrm{Zn}$ immersion times, the mechanical properties were gradually improved, while their corrosion resistance got worse. In practical applications, the requirements for material properties are multiple. In order to evaluate the properties of the material comprehensively and completely, it is necessary to balance the relationship between the mechanical properties and corrosion resistance. A preliminary and comprehensive assessment can be made for the comprehensive evaluation of 
the mechanical properties and corrosion resistance of a material. When the time of $\mathrm{Zn}$ immersion was too short (2 $\mathrm{min}$ ) or too long ( $8 \mathrm{~min})$, poor corrosion resistance or mechanical properties of the $\mathrm{Mg} / \mathrm{Al}$ intermetallic compounds $\beta$-phase $\left(\mathrm{Mg}_{17} \mathrm{Al}_{12}\right)$ and $\gamma$-phase $\left(\mathrm{Mg}_{2} \mathrm{Al}_{3}\right)$ were serious shortcomings that hindered further application of the materials. In contrast, when the $\mathrm{Zn}$ immersion time was $4 \mathrm{~min}$, the obtained intermetallic compounds had relatively optimal comprehensive properties. Moreover, controlling the thickness of the $\mathrm{Zn}$ immersion layer to adjust the different components of the intermetallic compounds could be the simplest method to achieve the optimal comprehensive performance, which may be of practical importance for surface modification of the materials.

\section{Conclusions}

Electrodeposition of $\mathrm{Al}$ coatings on $\mathrm{AZ91}$ alloys from $\mathrm{AlCl}_{3}-\mathrm{NaCl}-\mathrm{KCl}$ molten salts was achieved to prevent the substrate from rapidly corroding. Post-plating heat treatment processes were explored to improve coating adhesion and to maintain corrosion resistance. The conclusions can be drawn as follows:

(1) Different thicknesses of $\mathrm{Zn}$ films immersed on AZ91 alloy that varied from $0.2 \mu \mathrm{m}$ to $1.8 \mu \mathrm{m}$ were achieved by controlling the immersion times from $2 \mathrm{~min}$ to $8 \mathrm{~min}$. The compact and uniform Al coating with a thickness of $7 \pm 3 \mu \mathrm{m}$ was electrodeposited on the $\mathrm{Zn}$ film, which exhibited no clear relationship with the thickness of the $\mathrm{Zn}$ layer. After heat treatment at $350{ }^{\circ} \mathrm{C}$, the $\mathrm{Al}$ coating and the $\mathrm{Zn}$ layer were transformed to $\mathrm{Mg} / \mathrm{Al}$ intermetallic compounds $\beta$-phase $\left(\mathrm{Mg}_{17} \mathrm{Al}_{12}\right)$ and $\gamma$-phase $\left(\mathrm{Mg}_{2} \mathrm{Al}_{3}\right)$.

(2) Evaluated by nanoindentation testing, the nano-hardness properties of the AZ91D increased from $1.1 \pm 0.1 \mathrm{GPa}$ to $1.5 \pm 1.0 \mathrm{GPa}$ by $\mathrm{Zn}$ immersion, and to $2.4 \pm 0.5 \mathrm{GPa}$ by the electrodeposition of $\mathrm{Al}$ coatings. In addition, the obtained $\mathrm{Mg} / \mathrm{Al}$ intermetallic compounds induced by heat treatment led to a further improvement to reach $3.5 \pm 0.1 \mathrm{GPa}$.

(3) The hydrogen evolution tests and the potentiodynamic polarization proved that the $\mathrm{Zn}$ layer could not protect the $\mathrm{Mg}$ alloy matrix, while the electrodeposition $\mathrm{Al}$ coatings and heat treatment could improve corrosion resistance effectively. Compared with the $\mathrm{Al}$ coatings, the corrosion resistance of the $\mathrm{Mg} / \mathrm{Al}$ intermetallic compounds $\beta$-phase $\left(\mathrm{Mg}_{17} \mathrm{Al}_{12}\right)$ and $\gamma$-phase $\left(\mathrm{Mg}_{2} \mathrm{Al}_{3}\right)$ was a little bit worse.

(4) With the increase of the $\mathrm{Zn}$ immersion times, the thickness of the $\mathrm{Zn}$ layer increased and the mechanical properties were gradually improved, while their corrosion resistance got worse. When the $\mathrm{Zn}$ immersion time was $4 \mathrm{~min}$, the obtained intermetallic compounds had relatively optimal comprehensive properties.

Author Contributions: Conceptualization, T.Y. and H.Y.; methodology, K.W.; software, T.Y.; validation, K.W., H.J. and T.Y.; formal analysis, T.Y.; investigation, T.Y.; resources, Haiyan Jiang; data curation, T.Y.; writing — original draft preparation, T.Y.; writing —review and editing, W.W. and J.W.; visualization, J.W.; supervision, H.L.; project administration, W.D.; funding acquisition, Q.W. All authors have read and agreed to the published version of the manuscript.

Funding: This research was funded by Natural Science Foundation of China (51301110), and the China Post-Doctoral Science Foundation (2016M600311).

Institutional Review Board Statement: Not applicable.

Informed Consent Statement: Not applicable.

Data Availability Statement: The data presented in this study are available in this article.

Acknowledgments: The authors would like to gratefully acknowledge the financial support from the CAS Pioneer Hundred Talents Program, and the Science and Technology Innovation Action PlanInternational Enterprises Science and Technology Cooperation Program of Shanghai (17230732700).

Conflicts of Interest: The authors declare no conflict of interest. 


\section{References}

1. Tokunaga, T.; Ohno, M.; Matsuura, K. Coatings on Mg alloys and their mechanical properties: A review. J. Mater. Sci. Technol. 2018, 34, 1119-1126. [CrossRef]

2. Gray, J.E.; Luan, B.J. Protective Coatings on Magnesium and Its Alloys-A Critical Review. J. Alloys Compd. 2002, 336, 88-113. [CrossRef]

3. Shigematsu, I.; Nakamura, M.; Saitou, N.; Shimojima, K. Surface treatment of AZ91D magnesium alloy by aluminum diffusion coating. J. Mater. Sci. Lett. 2000, 19, 473-475. [CrossRef]

4. Christoglou, C.; Voudouris, N.; Angelopoulos, G.N.; Pant, M.; Dahl, W. Deposition of aluminum on magnesium by a CVD process. Surf. Coat. Technol. 2004, 184, 149-155. [CrossRef]

5. Meng, F.P.; Peng, S.; Xu, G.B.; Wang, Y.; Ge, F.F.; Huang, F. Structure of uniform and high-quality Al-doped ZnO films by magnetron sputter deposition at low temperatures. Thin Solid Films 2018, 665, 109-116. [CrossRef]

6. Zhang, R.F. Film formation in the second step of micro-arc oxidation on magnesium alloys. Corrosion Sci. 2010, 52, 1285-1290. [CrossRef]

7. Belova, I.V.; Heuskin, D.; Sondermann, E.; Ignatzi, B.; Kargl, F.; Murch, G.E.; Meyer, A. Combined interdiffusion and self-diffusion analysis in Al-Cu liquid diffusion couple. Scr. Mater. 2018, 143, 40-43. [CrossRef]

8. Cho, L.; Seo, E.J.; Sulistiyo, D.H.; Jo, K.R.; Kim, S.W.; Oh, J.K.; Cho, Y.R.; De Cooman, B.C. Influence of vanadium on the hydrogen embrittlement of aluminized ultra-high strength press hardening steel. Mater. Sci. Eng. A 2018, 735, 448-455. [CrossRef]

9. Rocca, E.; Juers, C.; Steinmetz, J. Corrosion behaviour of chemical conversion treatments on as-cast Mg-Al alloys: Electrochemical and non-electrochemical methods. Corros. Sci. 2010, 52, 2172-2178. [CrossRef]

10. Luo, X.X.; Yao, Z.J.; Zhang, P.Z.; Gu, D.D. Al2O3 nanoparticles reinforced Fe-Al laser cladding coatings with enhanced mechanical properties. J. Alloys Compd. 2018, 755, 41-45. [CrossRef]

11. Zhu, L.; Song, G. Improved corrosion resistance of AZ91D magnesium alloy by an aluminium-alloyed coating. Surf. Coat. Technol. 2006, 200, 2834-2840. [CrossRef]

12. Bu, H.; Yandouzi, M.; Lu, C.; Jodoin, B. Effect of heat treatment on the intermetallic layer of cold sprayed aluminum coatings on magnesium alloy. Surf. Coat. Technol. 2011, 205, 4665-4671. [CrossRef]

13. Bu, H.; Yandouzi, M.; Lu, C.; Jodoin, B. Post-heat Treatment Effects on Cold-Sprayed Aluminum Coatings on AZ91D Magnesium Substrates. J. Therm. Spray Technol. 2012, 21, 731-739. [CrossRef]

14. Zhao, M.C.; Liu, M.; Song, G.; Atrens, A. Influence of the $\beta$-phase morphology on the corrosion of the Mg alloy AZ91. Corros. Sci. 2008, 50, 1939-1953. [CrossRef]

15. Gamburg, Y.D.; Zangari, G. Theory and Practice of Metal Electrodeposition; Springer: Heidelberg, Germany, $2011 ;$ pp. 1-2.

16. Yao, T.Y.; Yang, H.Y.; Wang, K.; Jiang, H.Y.; Chen, X.B.; Liu, H.Z.; Wang, Q.D.; Ding, W.J. Effects of additive NaI on electrodeposition of $\mathrm{Al}$ coatings in $\mathrm{AlCl}_{3}-\mathrm{NaCl}-\mathrm{KCl}$ molten salts. Front. Chem. Sci. Eng. 2020, 1, 1-10. [CrossRef]

17. Yang, H.Y.; Guo, X.W.; Wu, G.H.; Ding, W.J.; Birbilis, N. Electrodeposition of chemically and mechanically protective Al-coatings on AZ91D Mg alloy. Corros. Sci. 2011, 53, 381-387. [CrossRef]

18. Liu, C.; Yang, H.; Wan, P.; Wang, K.H.; Tian, L.; Yang, K. Study on biodegradation of the second phase $\mathrm{Mg}_{17} \mathrm{Al}_{12}$ in $\mathrm{Mg}-\mathrm{Al}-\mathrm{Zn}$ Alloys: In vitro experiment and thermodynamic calculation. Mater. Sci. Eng. C 2014, 35, 1-7. [CrossRef] [PubMed]

19. Jiang, Y.B.; Tang, G.Y.; Shek, C.H.; Zhu, Y.H.; Xu, Z.H. On the thermodynamics and kinetics of electropulsing induced dissolution of $\beta-\mathrm{Mg}_{17} \mathrm{Al}_{12}$ phase in an aged Mg-9Al-1Zn alloy. Acta Mater. 2009, 57, 4797-4808. [CrossRef]

20. Song, G.; Shen, Q.X.; Zhu, M.L. A novel method for the preparation of Al-Mg intermetallic coating. Mater. Lett. 2011, 65, 480-482. [CrossRef]

21. Oliver, W.C.; Pharr, G.M. Measurement of hardness and elastic modulus by instrumented indentation: Advances in understanding and refinements to methodology. J. Mater. Res. 2004, 19, 3-20. [CrossRef]

22. Huang, H.; Winchester, K.; Liu, Y.; Hu, X.Z.; Musca, C.A.; Dell, J.M.; Faraone, L. Determination of mechanical properties of PECVD silicon nitride thin films for tunable MEMS Fabry-Pérot optical filters. J. Micromech. MicroEng. 2005, 15, 608-614. [CrossRef]

23. Yang, H.Y.; Chen, X.B.; Guo, X.W.; Wu, G.H.; Ding, W.J.; Birbilis, N. Coating pretreatment for Mg alloy AZ91D. Appl. Surf. Sci. 2012, 258, 5472-5481. [CrossRef]

24. Zhang, M.X.; Huang, H.; Spencer, K.; Shi, Y.N. Nanomechanics of Mg-Al intermetallic compounds. Surf. Coat. Technol. 2010, 204, 2118-2122. [CrossRef]

25. To, S.; Zhu, Y.H.; Lee, W.B. Microstructural Changes at the Ultra-Precision Raster Milled Surface of Zn-Al Based Alloy. Mater. Trans. 2008, 49, 698-703. [CrossRef]

26. Sun, H.Q.; Shi, Y.N.; Zhang, M.X.; Lu, K. Surface alloying of an Mg alloy subjected to surface mechanical attrition treatment. Surf. Coat. Technol. 2008, 202, 3947-3953. [CrossRef]

27. Yang, H.; Guo, X.; Wu, G.; Wu, G.H.; Ding, W.J.; Birbilis, N. Continuous intermetallic compounds coatings on AZ91D Mg alloy fabricated by diffusion reaction of Mg-Al couples. Surf. Coat. Technol. 2011, 205, 2907-2913. [CrossRef]

28. Fini, M.H.; Amadeh, A. Improvement of wear and corrosion resistance of AZ91 magnesium alloy by applying Ni-SiC nanocomposite coating via pulse electro-deposition. Trans. Nonferrous Met. Soc. China 2013, 23, 2914-2922. [CrossRef]

29. Zhang, J.; Yan, C.; Wang, F. Electrodeposition of Al-Mn alloy on AZ31B magnesium alloy in molten salts. Appl. Surf. Sci. 2009, 255, 4926-4932. [CrossRef] 
30. Birbilis, N.; Buchheit, R.G. Electrochemical Characteristics of Intermetallic Phases in Aluminum Alloys An Experimental Survey and Discussion. J. Electrochem. Soc. 2005, 152, 467-472. [CrossRef]

31. Searles, J.L.; Gouma, P.I.; Buchheit, R.G. Stress corrosion cracking of sensitized AA5083(Al-4.5Mg-1.0Mn). Metall. Mater. Trans. A 2001, 32, 2859-2867. [CrossRef]

32. Zhang, J.F.; Zhang, W.; Yan, C.; Du, K.; Wang, F.H. Corrosion behaviors of Zn/Al-Mn alloy composite coatings deposited on magnesium alloy AZ31B (Mg-Al-Zn). Electrochim. Acta 2009, 55, 560-571. [CrossRef] 